\title{
Towards a Consent Standard in the Law of Rape
}

The law traditionally has defined the crime of forcible rape ${ }^{1}$ to be an act of sexual intercourse accomplished by a man with a woman ${ }^{2}$ not his wife, ${ }^{3}$ by force and against her will. ${ }^{4}$ Although this definition reflects society's decision to punish a man as a rapist only when he has intercourse without the consent of his sexual partner, ${ }^{5}$ it does not disclose what acts by the respective parties may serve to convert sexual intercourse into criminal rape. To understand the law's working definition of rape it is necessary to examine not only the meaning of the formal elements of the crime, but also the subsidiary rules which the law has developed to aid the determination of guilt and innocence in particular instances.

This comment argues that, while the central substantive element of rape is nonconsent, the legal community has not yet developed a principled standard of effective nonconsent in rape. Instead, courts and legislatures have tried to manipulate evidence and other rules around an undefined issue, usually guided by questionable assumptions about rape complainants and rapists. In the process,

1 This comment will not cover the crime of statutory rape, generally defined as sexual intercourse with a female under a certain age, who is irrebuttably considered legally incapable of consent. See generally People v. Hernandez, 61 Cal. 2d 529, 393 P.2d 673, 39 Cal. Rptr. 361 (1964).

2 Theoretically, forcible rape also encompasses homosexual rape, and some states now incorporate such rape in the statutory definition. See, e.g., Mrch. Comp. Laws ANn. $\S \S$ $750.520 \mathrm{a}-.520 \mathrm{i}$ (1975). This comment will not deal with homosexual situations because the collateral issues raised by prison behavior and reform are complex and unique. However, the principles of consent that this comment will develop should apply to homosexual as well as heterosexual rape.

${ }^{3}$ See text and notes at notes $130-31$ infra.

- Federal courts instruct juries that "rape is the carnal knowledge of a woman forcibly and without her consent." United States v. Marshall, 266 F.2d 92, 95 n.2 (7th Cir. 1959). The majority of state criminal codes contain variations of this language. Typical are: "A male person of the age of 14 years and upwards who has sexual intercourse with a female, not his wife, by force and against her will, commits rape." Ill. Rev. Stát. §11-1(a) (1975); "Rape is an act of sexual intercourse, accomplished with a female not the wife of the perpetrator . . . (2) where she resists, but her resistance is overcome by force or violence; (3) where she is prevented from resisting by threats of great and immediate bodily harm, accompanied by apparent power of execution . . . ." CaL. Penal Code $\S 261$ (West 1970).

Although the current United States Code contains no general rape statute, the proposed federal criminal code includes a section on sex offenses. S.1, 94th Cong., 1st Sess. $\S \S 1641-46$ (1975).

s The Supreme Court has specifically recognized the central importance of consent in rape. Williams v. United States, 327 U.S. 711,715 (1946). 
they have lost sight of and failed to protect interests served by criminalization of rape. This comment explores the underlying reasons for the current confusion in the working definition of rape and suggests that the law's treatment of consent issues in other areas of the law offers valuable direction to legislatures and courts concurrently attempting to reform the legal treatment of rape.

Part I identifies the policies served by criminalization of rape, notes the failure of the legal system to fulfill these policies, and suggests that at least part of this failure may be attributed to subsidiary legal rules which unnecessarily hinder the system in identifying and punishing rapists. Part II continues in this vein with a brief examination of current controversies over the formal definition of rape and over admission of certain evidence in rape trials, with a view toward drawing out the erroneous assumptions which have distorted traditional rules of criminal law and have thereby forced the working definition of rape away from its central element. This section also suggests that both the traditional and reform treatments of these controversies place too much emphasis on categorical solutions to complex problems. Part III examines the turn-of-thecentury debate over the meaning of consent in cases of rape by subterfuge, arguing that neither that debate's assumption about female character, nor its treatment of rape as being immune from general principles of criminal law, nor its resolution of consent problems by convenient categorical rules should continue to influence the substance or tone of current thought about the meaning of consent in cases of forcible rape. Part IV then examines and compares the treatment of consent issues in other areas of the law with their treatment in rape law, concluding that both the formal and working definitions of nonconsent in rape should be brought more nearly in line with those in other areas of law.

\section{Purposes of Rape Statutes: In Theory and Practice}

The policies behind rape statutes are clear. Forcible rape threatens a woman's physical safety and denies her freedom of sexual choice and, at the same time, weakens the security and morality of society. ${ }^{6}$ Society's determination to protect women from the dual personal invasion of rape has shaped the traditional definition of the

- Some commentators accuse the legal system of using rape to protect male property rights in women. See, e.g., S. Brownmiller, Against Our Will: Men, Women and Rape 377 (1975) [hereinafter cited as Brownmiler]; Comment, Rape and Rape Laws: Sexism in Society and Law, 61 CALIF. L. REv. 919, 924-25 (1973). However, this negative approach seems to be giving way to a recognition that all society is harmed when rapists go unpunished. 
crime. While the sexual element of the crime is met by even slight penetration of the female sex organ by the male's, ${ }^{7}$ the requirement of nonconsent seeks to ensure that the accused has in fact denied the alleged victim of her sexual choice. To better protect women's physical safety, the law now recognizes that threats of great bodily harm, as well as actual brutality, satisfy the requirement of force. ${ }^{8}$ The criminal law ${ }^{9}$ purportedly serves these policies by providing a framework within which a victim can report a rape, the police can investigate the charge, the state can prosecute the accused, the trier of fact can decide guilt or innocence, and the court can assign a punishment to serve the ends of deterrence, retribution and rehabilitation.

In practice, though, the legal system performs poorly in fulfilling the purposes behind criminalization of rape. Because of the personal burdens and potential embarrassment involved in both investigation and trial, and perhaps because of the low probability of obtaining a conviction, a large proportion of rape victims do not report the crime at all. ${ }^{10}$ When an alleged rape is reported, police

7 "Sexual intercourse occurs when there is any penetration of the female sex organ by the male sex organ." ILL. REv. STAT. § 11-1(b) (1975). The proposed federal criminal code liberally defines "sexual act" to include anal and oral intercourse. S.1, 94th Cong., ist Sess. $\S 1646(a)(1)(1975)$.

8 See, e.g., Johnson v. United States, 426 F.2d 651, 654 (D.C. Cir.), cert. denied, 401 U.S. 846 (1970); Ewing v. United States, 135 F.2d 633, 635 (D.C. Cir. 1942), cert. denied, 318 U.S. 776 (1943); Beard v. State, 323 N.E.2d 216, 218 (Ind. 1975); State v. Gallup, 520 S.W.2d 619, 621 (Mo. App. 1975); State v. Hines, 286 N.C. 377, 380, 211 S.E.2d 201, 203 (1975).

This liberal approach to force is consistent with the empirical data available on rape. Menachim Amir's study, based on a sample of 646 rape victims and 1,292 offenders identified in police records of reported rapes occurring in Philadelphia between 1958 and 1960, found that 20.4 percent of rapes involved brutal beating; 24.7 percent, nonbrutal beating; 11.5 percent, choking; 28.5 percent, roughness; and 14.9 percent, no use of extrinsic force. $M$. Amir, Patterns in Forcible Rape 155 (1971) [hereinafter cited as Amir]. This data was corroborated by a 1973 study of 80 rape victims at Boston City Hospital, which found that 21 victims had been manhandled, over half had been threatened with a weapon, and 12 had succumbed to verbal threats. Burgess \& Holmstrom, The Rape Victim in the Emergency Ward, AM. J. Nursing 1740 (Oct. 1973).

Because Amir's study is the only comprehensive one available, it is extensively cited in the recent literature on rape. However, because the study is limited to reported rapes and most rapes are not reported, see text and note at note 10 infra, his conclusions do not rest on comprehensive data. Because of this inadequacy, this comment uses Amir's data only to show broad characteristics of rapists and victims.

- To redress the violation of individual rights involved, a rape victim can bring a civil action for sexual assault. Since rapists as a class tend to be judgment proof, it is rarely pursued.

10 After conducting a survey of 10,000 households, the National Opinion Research Center of The University of Chicago found that approximately 27 percent of actual rapes are reported. President's Commission on Law Enforcement \& Administration of Justice, The Challenge of Crime in a Free Society 23 (1967). Women do not report rape for many reasons. 
often "unfind" the complaint on the ground that the evidence available would not hold up in court." Of complaints that finally result in arrest ${ }^{12}$ and prosecution,,$^{13}$ only about half lead to convictions. ${ }^{14}$ Society's stated determination to protect women from rape by identifying and punishing rapists must be questioned, in light of its failure to do so more effectively. ${ }^{15}$

Much of this failure can be attributed to the legal rules that determine how a charge of rape is tried and punished. Society's abhorrence of rape is reflected in extremely severe punishments ${ }^{16}$ which tend to discourage convictions in all but the most violent cases of rape. ${ }^{17}$ Ironically, this same abhorrence creates a disbelief that any man could commit rape and a concomitant distrust of the complainant's accusation. ${ }^{18}$

Legal rules unique to rape trials formalize this distrust and add to the prosecution's burden of persuasion, which is already difficult to attain because the private nature of the act usually precludes

Some feel great shame; many fear humiliating reactions from parents, spouses or friends; some dread accusations of provocation or active participation; others fear retaliation by the attacker. "Whatever the reasons, the failure of victims to report rapes is itself a strong indication of the malfunctioning of rape laws and enforcement mechanisms." Comment, supra note 6, at 922. See also AMIR, supra note 8, at 27-29.

"According to the 1974 Uniform Crime Reports, 15 percent of all forcible rapes reported to police were "unfounded." FBI UNIForm Crime RePorts 22 (1974); see Comment, Police Discretion and the Judgment That a Crime Has Been Committed-Rape in Philadelphia, 117 U. PA. L. REv. 277 (1968).

12 Of the total forcible rapes reported and not "unfounded" in 1974, 51 percent were cleared by arrest. FBI UNIFORM CRIME REPORTS 24 (1974).

13 Of those men arrested, 60 percent were prosecuted. Id.

is Of those men prosecuted, 35 percent were found guilty of the substantive offense and 16 percent were convicted of lesser offenses. Id.

15 Compare notes 10-14 supra, with note 74 infra.

${ }_{16}$ Most states classify rape as a first or second degree felony, punishable by imprisonment of a minimum of four years to a maximum of life. See, e.g., ILL. Rev. STAT. \& 11-1(c) (1975); Mich. Comp. Laws ANN. § 750.520b(2) (1975).

17 The Chicago Jury Project's study of seventy-two rape trials found that in cases where there appears to be some form of contributory behavior on the alleged victim's part, the jury will find the defendant guilty of a lesser charge than rape, if that option is available, or acquit rather than convict of rape. Jury convictions for "simple" rapes, not involving circumstances of extrinsic violence, were much less frequent than convictions for "aggravated rape." $\mathrm{H}$. Kalven \& H. Zeisel, The Ambrican JuRy 250-54 (1966) [hereinafter cited as Kalven \& ZEISEL].

Though there can be plea bargaining to the lesser included offenses of fornication or assault, the former fails to fulfill the purpose of protecting safety and the latter ignores the violation of sexual choice. The preferable approach is gradation of sexual offenses and punishment on grounds of severity of sexual invasion and physical harm. See, e.g., Mich. Comp. Laws ANn. $\$ 750.520$ (1975); N.Y. Penal Law $\$ \$ 130.25$-.35 (McKinney 1975); S.1, 94th Cong., 1st Sess. §§ 1641(b), 1642(b) \& 2301(b)(3)-(4) (1975).

is See Landau, Rape: The Victim as Defendant, 10 Trial 19 (July-Aug. 1974) [hereinafter cited as Landau]. 
eyewitnesses. Most trial judges use a cautionary instruction, dating from Lord Hale's Pleas of the Crown, advising the jury to weigh the complainant's testimony carefully because the charge of rape is "easy to make, difficult to prove, and more difficult to disprove." Some jurisdictions will not hear an uncorroborated charge, while all juries seem informally to demand some corroboration. ${ }^{20}$ To exploit these and other advantages, the defense almost never waives a jury trial. ${ }^{21}$ Because a defense of consent "concedes essential facts of time, place, persons involved and the act of sexual intercourse in an attempt to legitimize the act," 22 the defense attorney aggressively tries to discredit the prosecution's evidence of nonconsent on crossexamination by making humiliating inquiries into the complaining witness' reputation, behavior, dress, acquaintances and sexual experience. ${ }^{23}$

\section{Current Controversies}

Current controversies concerning the formal elements of the crime of rape and the admissibility of evidence of the complainant's

13 These words come from the standard Iowa instruction, as cited in State v. Feddersen, 230 N.W.2d 510,514 (Iowa 1975), which is a representative instruction. The words are remarkably loyal to Hale's own: "It is true, rape is a most detestable crime, and therefore ought severely and impartially to be punished with death; but it must be remembered that it is an accusation easily to be made and hard to be proved; and harder to be defended by the party accused, though never so innocent." 1 M. HALE, Pleas of THE Crown 633, 635 (1680). Hale's words should be read with the knowledge that, at common law, a rape victim's testimony alone was sufficient to support a conviction, raising an apprehension of false accusations. $C f$. 7 J. Wigmore, Evidence $\S 2061$ (3d ed. 1940).

In Feddersen, the Iowa Supreme Court specifically disapproved the instruction because, inter alia, it constituted a comment on the evidence and applied a stricter test of credibility to the rape victim than to other witnesses in the trial or to victims of other crimes. 230 N.W.2d at 515. See also People v. Rincon-Pineda, 14 Cal. 3d 864, 538 P.2d 247, 123 Cal. Rptr. 119 (1975) (holding trial judges will no longer be permitted to give the Lord Hale instruction).

20 For general discussion of the corroboration requirement, which is beyond the scope of this comment, see Note, Corroborating Charges of Rape, 67 CoLum. L. Rev. 1137 (1967); Note, The Rape Corroboration Requirement: Repeal Not Reform, 81 YALE L.J. 1365 (1972). For a list of common types of corroborating evidence, see Allison v. United States, 409 F.2d 445, 448 n.8 (D.C. Cir. 1969).

${ }^{21}$ Rape ranks second only to murder in the number of cases in which the defendant prefers to take his chances with a jury rather than be tried by judge alone. KALVEN \& ZEISEL, supra note 17 , at 26 .

${ }^{22}$ Hibey, The Trial of a Rape Case: An Advocate's Analysis of Corroboration, Consent and Character, 11 AM. CRIM. L. REv. 309, 321-22 (1973).

${ }^{23}$ For a discussion of trial tactics and an example of a defense attorney's crossexamination of the complaining witness on the issue of consent, see id. at 321-25. In addition, the mere recounting of the circumstances of an alleged rape in a courtroom setting is embarrassing and troubling for a complainant, as is direct questioning by the state's attorney about sexual details of the act in question and her past. See generally Blumberg \& Bohmer, The Rape Victim and Due Process, 80 CASE \& CoM., Nov.-Dec. 1975, at 3, 6-8. 
prior sexual activity serve to illustrate further the divergence between the purposes and practices of rape law. This section examines these controversies, concluding that the central definitional element of rape is nonconsent and that the subsidiary rules unique to rape are based on erroneous and prejudicial assumptions. In large part, it is these assumptions that account for the failure of rape law to fulfill its purposes.

\section{A. Defining the Crime: The Force-Resistance-Consent Controversy}

Rape statutes use the phrases "by force" and "against her will" and "without her consent" sometimes synonymously and sometimes as distinct elements, ${ }^{24}$ a practice that has generated a great deal of confusion. Although courts have become more liberal in finding the amount of force necessary to satisfy that element, ${ }^{25}$ force continues to be important as an indicator of consent. Nonetheless, the fictions and artificial distinctions necessary to satisfy the requirements of both force and nonconsent in certain situations ${ }^{26}$ have led some commentators to suggest that force be dropped as a separate element. ${ }^{27}$ Others, arguing that the law should focus on the behavior of the assailant rather than on his victim's response, have effectively proposed that force should be the only element in addition to intercourse. ${ }^{28}$

Although the phrases "without her consent" and "against her will" do inevitably focus attention on the complainant's behavior, they suggest subtly different meanings. While the first implies only

${ }^{24}$ For examples of the different combinations of phrasing, see note 4 supra.

${ }^{25}$ See text and note at note 8 supra.

${ }^{26}$ See, e.g., People v. Clarke, 50 III. 2d 104, 277 N.E.2d 866 (1971), where the accused had allegedly raped the complainant after breaking into her home, tying her hands, threatening to kill her, and covering her head with a pillow. The defendant argued that there was insufficient evidence of force to establish beyond a reasonable doubt that the woman was raped against her will. The Illinois Supreme Court found that the defendant's threat, coupled with his denying her a chance to see a weapon, constituted illegal force. Although the breaking in and binding of hands also constituted illegal force, the court saw those actions as negating consent; it then had to struggle to find independent proof of force. See also text and note at note 38 infra.

${ }^{27}$ Cf. Puttkammer, Consent in Rape, 19 ILL. L. REv. 410, 414-15 \& n.18 (1925) [hereinafter cited as Puttkammer, Consent].

${ }^{28}$ Landau has proposed a law dividing rape into different degrees to reflect differences in amount of force employed in various situations. Landau, supra note 18 , at 22 . Brownmiller also proposes a standard which focuses on the behavior of the alleged attacker, because she believes the current rules protect male interests by gauging the victim's behavior rather than finding force or threat of force to be conclusive in and of itself, as it is in submission to robbery or assault. BRowNMILLER, supra note 6 , at 384-85. 
that the victim withheld active approval or expressed nonconsent, the second connotes active resistance. ${ }^{29}$ This difference in emphasis has led some courts to consider resistance as a distinct element of the crime, in addition to force and nonconsent, with harsh results for the prosecution. ${ }^{30}$ Indeed, one commentator has gone so far as to propose a statute that would define rape solely in terms of a resistance standard, ${ }^{31}$ in part to permit formulation of an objective standard for rape trials and to remove "the woman's often distorted opinion from the law of forcible rape." 32

Despite this seemingly sharp disagreement, it is evident that juries, courts and commentators consider assailant force and victim resistance primarily as indicators of nonconsent. Where the force used was extreme $\mathrm{e}^{33}$ or where the prosecution presents a third party witness to criminal force,$^{34}$ the trier of fact generally assumes that the victim did not consent to intercourse. ${ }^{35}$ While the law traditionally demanded "utmost resistance" from the complainant in order to be sure she had submitted rather than consented, ${ }^{36}$ the prosecu-

29 See Puttkammer, Consent, supra note 27, at 427-28.

30 See text and note at note 36 infra. Juries may also demand evidence of resistance. In one case, described in a recent law review article, two complainants filed rape and sodomy charges against a man who had allegedly beaten and sexually assaulted them in a dormitory washroom. The prosecution explained that the women feared the man had a gun, presented medical evidence of their severely bruised condition after the incident, and corroborated their story with the testimony of a roommate who saw them emerge from the bathroom with the accused. The jury acquitted the defendant on the ground that the force used was not sufficient to justify the complainants' submission, but one juror revealed that the jury believed the women had not resisted enough. Note, The Victim in a Forcible Rape Case: A Feminist View, 11 AM. CRIM. L. REv. 335, 346 (1973).

31 Under the first part of a two-pronged test, the jury would have to decide whether the assailant used force to overcome resistance "at least as great as the maximum resistance a female in the circumstances of the alleged victim could reasonably offer to prevent penetration while avoiding serious risk of death or serious bodily injury." If she did not resist, the jury's second task would be to decide whether the situation was so imminently harmful as to justify her passivity, by weighing the severity and credibility of any threats made or the nature and effects of any drugs administered. Note, The Resistance Standard in Rape Legislation, 18 Stan. L. REv. 680, 688 (1966). In effect, this test would require that a man use force or serious guile, but then would test the sufficiency of the force or guile by setting an objective standard of resistance to be overcome.

${ }^{32}$ Id. at 684-85.

3 KALven \& Zeisel, supra note 17, at 253 (Table 72).

* See, e.g., People v. Hill, 28 Ill. 2d 438, 192 N.E.2d 873 (1963).

${ }^{35}$ Where the jurors believe that the complainant "assumed the risk" of an attack, however, even evidence of extreme brutality may not convince them that she did not freely consent to intercourse. See note 65 infra.

34 For the classic example of the utmost resistance standard, see Reynolds v. State, 27 Neb. 90, 91, 42 N.W. 903, 904 (1889). The prosecution had to prove that the defendant either overcame the complainant's utmost resistance or so frightened her as to render her "insensible" and therefore incapable of resistance. See also State v. Hoffman, 228 Wis. 235, 280 N.W. 357 (1938). 
tion now must demonstrate only "good faith" resistance, measured in relation to the total circumstances of the alleged attack. ${ }^{37}$ Furthermore, where the complainant clearly was incapable of effective consent, as in cases of victim unconsciousness, it is settled that the force requirement is satisfied merely by the amount of force necessary to perform the sexual act. ${ }^{38}$ Even advocates of force and resistance tests concede that their standards are based ultimately on the probabilities of actual victim consent. ${ }^{39}$ Continuous juggling of the elements of the crime by courts and commentators reflects an urge toward administrative simplicity, a search for an external standard by which to measure the subjective element of nonconsent. At the same time, this interplay reveals a conviction that the central substantive issue in rape is consent..$^{40}$

\section{B. The Controversy over Admission of Prior Sexual Activity Evidence}

Given the subjective nature of consent and the general lack of witnesses to an alleged rape, the courts and legislatures have had great difficulty in deciding what types of evidence should be admitted to show consent to the specific act of intercourse in question. The most controversial question concerns admissibility of evidence of the complainant's prior sexual activity with the defendant or with other men." Wigmore advocated that all evidence of a complain-

${ }^{37}$ See, e.g., People v. Montgomery, 19 Ill. App. 3d 206, 210-11, 311 N.E.2d 361, 364 (1974); State v. Verdonne, 337 A.2d 804, 810 (R.I. 1975); Dumer v. State, 64 Wis. 2d 590, 608, 219 N.W.2d 592, 602 (1974); State v. Herfel, 49 Wis. 2d 513, 518-19, 182 N.W.2d 232, 235 (1971).

xs See, e.g., People v. Ing, 65 Cal. 2d 603, 612, 422 P.2d 590, 595, 55 Cal. Rptr. 902, 907 (1967); Lee v. State, 322 So. 2d 751, 752 (Miss. 1975); cf. United States v. Medley, 452 F.2d 1325, 1327 (D.C. Cir. 1971).

${ }^{32}$ For example, the Model Penal Code states that a man is guilty of rape if he, inter alia, compels a woman not his wife "to submit by force or by threat of imminent death, serious bodily injury . . . ;" but unlawful force is defined as "force . . . which is employed without the consent of the person against whom it is directed." Model Penal Code $\$ \S 213.1,3.11(1)$ (Proposed Off. Draft 1962).

Those who favor exclusive reliance on a resistance standard admit the relationship between nonconsent and resistance: "Sexual intercourse becomes rape only when the woman manifests or is unable to manifest her unwillingness to participate and the male has intercourse with her by taking advantage of her inability or by overcoming her resistance." Note, supra note 31 , at $687-88$.

to A possible explanation for the law's retention of a residual force requirement (at least where the alleged victim is otherwise capable of effective consent, see text and note at note 38 supra) is its reluctance to recognize various forms of nonphysical coercion in the rape context. See generally text and notes at notes 132-47 infra.

"See, e.g., Washburn, Rape Law: The Need for Reform, 5 N. Mex. L. Rev. 279 (1975); Note, California Rape Evidence Reform: An Analysis of Senate Bill 1678, 26 Hastings L.J. 
ant's general reputation for unchastity ${ }^{42}$ and specific instances of her prior sexual activity should be admissible to show consent ${ }^{43}$ and to impeach the credibility of the complaining witness." Almost all jurisdictions utilize this approach, though a majority follow the modification embodied in an exclusionary rule that restricts admission of evidence of specific unchaste action with men other than the defendant to cross-examination of the complainant. ${ }^{45}$ As a result, the defense may present evidence of the alleged victim's reputation for unchastity and cross-examine her about her sexual activity, a term which conceivably covers anything from her actual relationships to her mode of dress. ${ }^{46}$

1551 (1975) [hereinafter cited as HASTINGS Note]; Note, Limitations on the Right to Introduce Evidence Pertaining to the Prior Sexual History of the Complaining Witness in Cases of Forcible Rape: Reflection of Reality or Denial of Due Process? 3 Hofstra L. Rev. 403 (1975) [hereinafter cited as Hofstra Note]; Comment, Rape in Illinois: A Denial of Equal Protection, 8 John Marshall J. Prac. \& Proc. 457 (1975); Comment, The Rape Victim: A Victim of Society and the Law, 11 WillameTte L.J. 36 (1974).

12 Unchastity means that a woman, if unmarried, is not a virgin. If the woman is married, her extramarital sexual activity is considered unchaste. To be relevant in rape, such unchastity must have occurred prior to the intercourse at issue. People v. Eilers, 18 Ill. App. 3d 213, 217, 309 N.E.2d 627, 630 (1974).

s3 $1 \mathrm{~J}$. WigMORE, EvIDENCE $\$ 62$ (3d ed. 1940) (general character for unchastity); 3A J. Wigmore, Evidence $\S 200$ (Chad. rev. ed. 1970) (specific acts of unchastity). For modern examples of this position, see Brown v. State, 50 Ala. App. 471, 474, 280 So. 2d 177, 179 (Crim. App. 1973); People v. Stephens, 18 Ill. App. 3d 971, 977-78, 310 N.E.2d 824, 830 (1974).

" 3A J. Wigmore, Evidence $\$ 924 a$ (Chad. rev. ed. 1970) (general character); id. \$ 979(4) (specific acts). It is interesting that Wigmore opposed admission of evidence of bad character for a specific character trait to impeach a witness in all cases except rape. He feared that a party would use such evidence for revenge or as a threat to coerce suppression of opposing testimony and thereby give the trial "a flavor of filth and rancor which is at once unnecessary and harmful to justice." Id. $\S 924$, at 736 .

15 See, e.g., Rice v. State, 35 Fla. 236, 238-39, 17 So. 2d 286, 287 (1895); State v. Jack, 285 So. 2d 204, 208 (La. 1973); State v. Yowell, 513 S.W.2d 397, 403-04 (Mo. 1974). For a discussion of the exclusionary rule, see C. McCoRmick, Evidence $\$ 42$ (2d ed. 1972); 3A J. Wigmore, Evidence $\$ \$ 977,979$ (Chad. rev. ed. 1970). The Federal Rules of Evidence codify the exclusionary rule by allowing cross-examination, but not direct testimony, to disclose specific instances of misconduct to prove a character trait or to discredit a witness. FED. R. Evid. $\$ \S 405,608$ (1975). See also B. CARdozo, The Nature of the Judicial Process 156 (1928) (arguing against the exclusionary rule); HoFsTra NoTE, supra note 41, at 410-12.

"See text and note at note 23 supra. The prior sexual activity rule is so entrenched that in Virgin Islands v. John, 447 F.2d 69 (3d Cir. 1971), the Third Circuit found prejudicial error where a trial judge failed to instruct the jury that evidence of the complainant's bad reputation for chastity is "of substantial probative value in judging the likelihood of her consent," id. at 73, quoting Hicks v. Hiatt, 64 F. Supp. 238, 243 (M.D. Pa. 1946) (citing 1 J. Wigmore, EVIDENCE $\$ 62$ (3d ed. 1940)), and has "a direct bearing on her credibility." 447 F.2d at 7374, relying on Commonwealth v. Eberhardt, I64 Pa. Super. 591, 603-04, 67 A.2d 613, 619 (1949) (citing $3 \mathrm{~J}$. Wigmore, Evidence $\S 924$ a (3d ed. 1940)).

The Eighth Circuit has ruled that a lower court committed prejudicial error in excluding evidence to show that the complainant had been unchaste with men other than the defendant, though the lower court had admitted evidence indicating that the woman had con- 
Recognition that evidence of prior sexual activity is often unduly prejudicial ${ }^{47}$ and usually an unnecessary invasion of the complainant's privacy, coupled with pressure from feminist and civil rights groups for reform, has forced most legislatures to reexamine the traditional Wigmore approach. ${ }^{48}$ Some states have amended rape statutes or evidence codes to limit admission of such evidence, generally by requiring in camera hearings in which the judge must weigh the probative value of offered evidence of prior sexual activity against its prejudicial impact. ${ }^{49}$ California courts admit unchastity evidence under certain restrictions to impeach the complaining witness, ${ }^{50}$ but not to show her tendency to consent at the time of the alleged rape..$^{51}$ Michigan has taken the most radical approach by repealing its rape statute and enacting a criminal sexual conduct statute that declares all evidence of the complainant's prior sexual activity with persons other than the accused per se

sented to the defendant's advances before. Packineau v. United States, 202 F.2d 681 (8th Cir. 1953). The court felt that evidence of "her concupiscence-of her having sexual lust and unlawfully indulging it" must be admitted to balance the jury's view of her as a "very refined" and unsophisticated girl. Id. at 687. Without a trace of irony, the court also found prejudicial error in the lower court's allowing the defendant to be questioned about his illegitimate family and arrests nor disorderly conduct because "[a]cts of misconduct, not resulting in conviction of a crime, are not the proper subject of cross-examination to impeach a witness." Id. at 687, citing Echert v. United States, 188 F.2d 336, 343 (8th Cir. 1951).

${ }^{17}$ The Chicago Jury Project found that the jury weighs evidence of prior unchastity evidence harshly against the prosecution, even in cases that involve serious violence. Illustrative is a verdict which the judge called "a travesty of justice." Because the victim had two illegitimate children and the defendants claimed she was a prostitute, the jury acquitted three men who kidnapped a woman on the street at 1:30 a.m., took her to an apartment, and attacked her. KALVEN \& ZEISEL, supra note 17, at 25.

$1 \times$ N.Y. Times, June $4,1975, \S 1$, at 1 , col. 2 (city ed.).

19 For example, under 1974 reforms in Iowa's rape statute, the trial court must conduct a hearing in camera as to relevancy of evidence of previous sexual conduct and must control admission of such evidence at trial, but in no event may it admit evidence concerning sexual acts committed more than one year before the crime with persons other than the defendant. Iowa Code AnN. § 782.4 (1975). See also Tex. Penal Code $\S 21.02$ (1975).

so California law requires the defendant to file a written motion stating that the defense has an offer of proof of the relevancy of evidence of sexual activity proposed to be presented to discredit the complaining witness, accompanied by an affidavit stating the offer of proof. If the court finds the offer sufficient, it must hold a hearing out of the presence of the jury where the complainant can be questioned about the offer of proof. If the court finds the proposed evidence relevant and not unduly prejudicial, it must determine what evidence may be introduced by the defendant, and the nature of the questions to be permitted. CAL. Evid. CODE $\$ 782$ (West 1975).

s1 CAL. Evid. CodE $\S 1103$ (West 1975). For a discussion of the interplay between and the inadequacies of these two evidence rules as applied to rape cases, see Hastings Note, supra note 41 . 
inadmissible, unless it shows the source of semen, pregnancy or disease..$^{52}$

The extreme approaches exemplified by Wigmore on one side and Michigan on the other utilize broad inflexible rules for judicial treatment of evidence of a complainant's prior sexual activity. The traditional all-inclusive approach creates exceptions to the basic principle that evidence must be relevant and nonprejudicial to be admitted ${ }^{53}$ and disregards resulting prejudice to the prosecution and humiliation to a complaining witness. ${ }^{54}$ The general or per se inadmissibility approach involves potential infringement of a defendant's sixth amendment rights to confront witnesses against him and to present witnesses on his own behalf. ${ }^{55}$ Neither extreme position seeks to ensure a rational balance of legal rights.

\section{Erroneous Assumptions About Rape}

Several basic assumptions about rape complainants and rapists, all tending to disadvantage the prosecution, have shaped the development of traditional evidence rules and resistance requirements. Judicial delay in assimilating modern empirical data and commentary that demonstrate the invalidity of these beliefs, together with perhaps equally unsupportable expectations about rape victims, have helped generate the recent movement to reform the law of rape. However, the legal community cannot rationally study substantive and procedural rape law, nor discuss proposed amendments, without first identifying the questionable premises that form the foundation of rape law.

Admission of evidence of prior sexual activity is premised on

52 Mich. Comp. Laws Ann. 750.520j(1) (1975). In People v. Whitfield, 58 Mich. App. 585, 228 N.W.2d 475 (1975), the appellate court decided it was not reversible error for the trial court to exercise its discretion to prevent defense counsel from questioning the complainant on her prior sexual activity with third parties. Though the court did not apply the recently enacted criminal sexual conduct statute, it noted that the public policy of that statute supported the trial judge's use of discretion. Id. at 592, 228 N.W.2d at 478-79.

s3 See Washburn, supra note 41, at 294-301.

5t See generally Note, supra note 30; Comment, supra note 6.

${ }^{35}$ One commentator, basing his views on Davis v. Alaska, 415 U.S. 308 (1974), contends that the Supreme Court would find the Michigan statute unconstitutional on sixth amendment grounds, unless the state could prove that such evidence is never relevant to consent. Horstra Note, supra note 41, at 417-25. The author stresses the fact that the Court, in Giles v. Maryland, 386 U.S. 66 (1967), refused to find prior sexual activity evidence irrelevant to consent, "although ample opportunity existed for one of the justices who was so inclined to doubt its relevancy." Id. at 413 \& n.6. This argument is weak because the relevancy of prior sexual activity evidence was not the main issue in Giles, which, at any rate, was a 3-2-3 decision. 
the belief that an unchaste woman is more likely than a chaste one to have consented to any particular sexual encounter. ${ }^{56}$ But in an era when premarital relations are not unusual, ${ }^{57}$ this belief leads to the indefensibly broad inference that women generally tend to consent to sexual advances, ${ }^{58}$ regardless of the nature of their prior sexual experiences, their previous relation to the defendant or other circumstances present in each case. The result is that once a woman has voluntarily engaged in intercourse, the law grants less protection to her right to refuse intercourse in the future, without consideration of whether her past decision expresses anything about the likelihood of her having exercised her choice in the present case. Nonetheless, because juries still accept the traditional premise and weigh any evidence of the complainant's past sexual activity harshly against the prosecution's case, ${ }^{59}$ the danger of prejudice is substantial. In view of all these considerations, a strong argument can be made for holding that only evidence of prior sexual relations with the defendant ${ }^{60}$ or of indiscriminate promiscuity ${ }^{61}$ should be admissible to prove consent.

A related premise is that the behavior of a rape complainant, whether she is sexually experienced or not, invited or, to use the modern sociological phrase, precipitated the sexual attack. ${ }^{62}$ In the Chicago Jury Project, Professors Kalvan and Zeisel found that the jury, applying an informal assumption of risk test, goes beyond the issue of consent "to weigh the woman's conduct in the prior history of the affair ... and is moved to be lenient with the defendant whenever there are suggestions of contributory behavior on her part." 63 The range of supposedly contributory behavior extends from

st See 1 J. Wigmore, Evidence $\$ 62$, at 464-67 (3d ed. 1940); Virgin Islands v. John, 447 F.2d 69, 73 (3d Cir. 1971); Coles v. Peyton, 389 F.2d 224, 227 (4th Cir. 1968); People v. Johnson, 106 Cal. 289, 39 P. 622 (1895); People v. Eilers, 18 Ill. App. 3d 213, 217, 309 N.E.2d 627, 630 (1974). For a general discussion, see Willamette Comment, supra note 41.

${ }_{57}$ Nearly three-quarters of all white single women have had premarital intercourse by age 25. M. Hunt, Sexual Behavior IN THE 1970s 149 (1974). Approximately 70 percent of all presently married or divorced white females have had extramarital intercourse. Id. at 260.

5x See note 46 supra.

59 See text and notes at note 47 supra \& note 65 infra.

60 Even Michigan law, which makes most evidence of a complainant's prior sexual activity per se inadmissible, leaves to judicial discretion the decision whether to admit evidence of prior sexual activity with the defendant. Mich. Comp. Laws ANN. § 750.520j (1975).

ot The basis of the exclusionary rule itself is said to be that evidence of intercourse with a particular person on a particular occasion does not indicate a tendency to consent to all intercourse, though a general reputation for unchastity may. See, e.g., Rice v. State, 35 Fla. 236, 238-39, 17 So. 286, 287 (1895).

${ }_{62}$ See AMIR, supra note 8, at 259-76; BrownmilleR, supra note 6, at 353.

${ }^{63}$ KAI,vEN \& ZEISFI, supra note 17, at 249. 
a casual discussion with a stranger at a party, to the unwary practice of hitchhiking, to an evening spent with a boyfriend. ${ }^{64}$ Expectations of victim precipitation color jury deliberation on nonconsent, causing the jurors to focus on the complainant's behavior in getting into and out of a sexual encounter. ${ }^{65}$ This phenomenon is exaggerated by the common belief that rape does not occur between acquaintances, a premise which survives despite evidence that over half of all forcible rapists know their victims to some extent. ${ }^{66}$ To hold a woman legally responsible for the effect that her everyday activity has on men around her is both unrealistic and unfair. ${ }^{67}$ Even a woman who agrees to petting ought not to lose her right to refuse intercourse. ${ }^{68}$ Evidence rules and instructions which encourage the

4 For an approving view of the theory of victim precipitation, see Schiff, Statistical Features of Rape, 14 J. For. Scr. 102, 105 (1969). But cf. BRownmilter, supra note 6, at 354; WillametTe CoMment, supra note 41 , at 50 .

Suggestions that victim precipitation is common are contradicted by D. MuLviHtLL, Crimes of Viol.ence. a Staff Report to the National Commission on the Causes and Prevention of Violence 226 (1969), cited in Brownmlller, supra note 6 , at 355 , which reports that victim precipitation, defined as covering situations where "the victim agreed to sexual relations but retracted before the actual act or when she clearly invited sexual relations through language, gestures, etc.," occur in only 4.4 percent of all rapes. Amir found 19 percent of all rapes to be precipitated, but he included all cases which the offender interpreted as such. Amir, Forcible Rape, 31 Fed. Probation 51 (1967).

Amir's finding that most rapes are planned well in advance would seem to support the conclusion that precipitated rapes, however defined, are uncommon. He reports that 71 percent of all rapes are completely planned and 11 percent partially planned, while only 16 percent are "explosive events." AMIR, supra note 8, at 142.

"S Kalven \& ZeISEL, supra note 17, at 249-54. The jury can take assumption of risk "to a cruel extreme." One jury acquitted a defendant, who had broken the complainant's jaw in two places, when it learned the parties might have had intercourse on prior occasions. Id. at 251. Concern with the precipatory behavior of the woman apparently overrides the strong jury desire to punish violent, brutal attackers harshly. Id. at 252-54. In light of Amir's finding that the closer the relationship between the victim and offender, the greater the violence used against the woman, such a position seems particularly unwarranted. AmIR, supra note 8 , at 245.

"Amir found that strangers comprise 42.3 percent of forcible rapists; strangers with a general knowledge of the victim, 9.6 percent; acquaintance, 14.4 percent; close neighbor, 19.3 percent; close friend or boyfriend, 6 percent; family friend, 5.3 percent; relative, 2.5 percent. AMIR, supra note 8 , at 234 . These data contradict both the common notion that rape generally occurs between total strangers and the conflicting myth that rape charges tend to be made by women who have been intimate with their alleged attackers. Id. at 245-46. Consistent results were reached in a physician's study of 100 alleged rape victims who came to him for treatment. Schiff, supra note 64.

In their study of victimology and rape, Weis and Borges found that because of prevailing stereotypical conceptions of rape even participants in a rape situation often do not define it as such. Weis \& Borges, Victimology and Rape: The Case of the Legitimate Victim, 8 Issues in Criminology 71, 87 (1973) [hereinafter cited as Weis \& Borges].

"7 Since most rapes occur on the street, in the home or in the automobile, there is no safe place to avoid rape. See AMIR, supra note 8, at 145; Brownmilier, supra note 6, at 186.

${ }^{6 x}$ See Brownmilter. supra note 6, at 354; D. Russeld, The Politics of Rape 271 (1974). 
jury to indulge its notions of victim precipitation fail to protect a woman's freedom of sexual choice.

A third premise of traditional rape law is that unchaste women are untruthful in general and often bring false charges of rape. Wigmore, who believed that unchaste women are pathological liars, ${ }^{69}$ proposed that no judge let a sex offense charge go to the jury unless the complainant's social history and mental makeup had been examined and testified to by a physician. ${ }^{70}$ Though modern courts do not take so distrustful an approach, ${ }^{71}$ they nonetheless instruct juries that unchastity has a bearing on credibility, ${ }^{72}$ at least where consent to an alleged rape is at issue It is still commonly supposed that a woman who has engaged in illicit sexual intercourse will bring a false rape charge for reasons of guilt, revenge or self-protection. ${ }^{73}$ In light of the time, trauma and humiliation involved in a rape trial, common sense alone would cast doubt on the validity of these suppositions. Empirical data supports this hypothesis, demonstrating that only a minute percentage of rape reports made to police are in fact false. ${ }^{74}$

Distrust of the complainant's credibility has led to an exaggerated insistence on evidence of resistance. ${ }^{75}$ When the prosecution

89 [Rape complainants'] psychic complexes are multifarious, distorted partly by inherent defects, partly by diseased derangements or abnormal instincts, partly by bad social environment, partly by temporary physiological or emotional conditions . . . . The unchaste. . . mentality finds incidental but direct expression in the narration of imaginary sex incidents of which the narrator is the heroine or the victim. On the surface the narration is straight-forward and convincing.

3A J. Wigmore, Evidence $§ 924 a$, at 736 (Chad. rev. ed. 1970). The psychologists and psychiatrists that Wigmore cites to support his views focus on charges made by the mentally ill. Id.

${ }^{70}$ Id. at 737.

"Rather than making psychiatric examinations mandatory, most jurisdictions grant the judge discretion to order an exam when there is a compelling reason. See Comment, supra note 6, at 933-34; Comment, Evidence, Sex Offenses, and Credibility of Complaining Witness, 43 Iowa L. REv. 650 (1958); Note, Criminal Law-Psychiatric Examination of Prosecutrix in Rape Cases, 45 N.C.L. Rev. 234 (1966); Annot., 18 A.L.R. $3 d 1433$ (1968).

72 See, e.g., Virgin Islands v. John, 447 F.2d 69, 73-74 (3d Cir. 1971).

${ }_{73}$ Though admitting that the central issue in rape will likely be consent, the framers of the Model Penal Code labeled it "a subtle, psychological problem in view of social and religious pressures upon the woman to conceive of herself as victim, rather than collaborator." Modei. Penal Code $\S 207.4$, Comment at 264 (Tent. Draft No. 4 1955). See also Note, supra note 30 .

7s When New York City developed a Rape Analysis Squad commanded by policewomen, the officers found only 2 percent of rape complaints were false, about the same false report rate noted in other felonies. BrownMLLLer, supra note 6 , at 366 .

${ }_{75}$ An advocate of a resistance standard has declared that because "current psychological evidence indicates the unreliability of a woman's report of the incident, nothing should be left to the conceivably unreasonable opinion of the alleged victim." Note, supra note 31, at 683 . 
can show that a woman fought the intercourse or was absolutely paralyzed by fear, the jury is more likely to view the defendant as an attacker rather than a seducer. But, since most rapists meet resistance with increased violence, ${ }^{76}$ the courts do not further the purpose of rape statutes to protect physical safety by overemphasizing the resistance requirement.

This is not to suggest that judging rape solely in terms of assailant force is the solution. Rape victims, like victims of an assault or robbery, tend to demonstrate at least their unwillingness to submit. ${ }^{77}$ The lesson seems to be that the trier of fact should be permitted to measure consent by weighing both the acts of the alleged attacker and the response of the alleged victim, rather than being required to focus on one or the other.

Perhaps the most basic premise underlying the traditional rules of rape law is that a jury will sympathize with the alleged victim. ${ }^{78}$ The Chicago Jury Project, however, has shown that jury prejudice operates against the prosecution in rape trials, ${ }^{79}$ perhaps because the evidence rules have been too successful in protecting the defendant's right to be considered innocent, perhaps because of the high

Even the subjective test of good faith resistance, see text and note at note 37 supra, is based on the belief that a nonconsenting woman will physically express her feelings, a view that has been challenged in legal-psychological commentary. Weis and Borges suggest that when a woman is faced with a sexual attack and realizes her psychological and physical inability to protect herself, she is immobilized by fear, at least until she perceives and defines the situation, at which time it may be impossible to fight, flee or summon help successfully. Weis \& Borges, supra note 66, at 83.

According to a second theory, a woman, though not immobilized by fear, may still be incapable of responding to force with force. Because a woman is trained in the feminine traits of submissiveness, passivity and weakness, it is theorized she knows neither how to fight nor how to predict her assailant's response if she hurts him. Proponents of this view argue that it is unfair to castigate a woman for behavior that conforms to an acculturated pattern. $D$. Russell, The Politics of Rape 268, 271 (1974).

Brownmiller has argued that a woman might refuse to resist even if she is perfectly conscious of the impending rape and perfectly competent to fight back. Realizing that she faces an irrational and violent attacker, "[a] quid pro quo-rape in exchange for life, or rape in exchange for a good-faith guarantee against hurtful or disfiguring physical damage-dominates the female mentality in rape." BrownmiLLER, supra note 6, at 358-59. See also State v. Herfel, 49 Wis. 2d 513, 518, 182 N.W.2d 232, 235 (1971).

76 Amir, supra note 8 , at 164 .

${ }^{37} 26$ percent of all reported rape offenses consist of attempts or assaults with intent to rape. FBI UNIFORM CRime REPORTS 22 (1974). Thus it is probable that many women who resist do successfully avoid rape.

7x "The real victim, however, too often ... is the innocent man, for the respect and sympathy naturally felt by any tribunal for a wronged female helps to give easy credit to . . . a plausible tale." 3 A J. Wigmore, Evidence $\$ 924 a$, at 736 (Chad. rev. ed. 1970). See also Packineau v. United States, 202 F.2d 681, 687 (8th Cir. 1953).

" See generally Kalven \& ZeISEL, supra note 17, at 250-54. 
criminal sanctions involved, perhaps because of the common misconceptions about rape victims discussed above. ${ }^{-80}$ Although evidence reforms based on this recent understanding of the antiprosecution bias undoubtedly minimize jury distrust of a complainant's testimony, they, like the old rules, assume that a jury cannot weigh relevant, nonprejudicial evidence fairly to decide the credibility issues underlying consent. In similar fashion, currently proposed force and resistance tests reflect the desire for an administratively simple external measure of consent, at the risk of demanding more or less than can be reasonably expected from a woman faced with a request or demand for intercourse. It is submitted that neither the traditional nor the reformed categorical approaches to rape law focuses sufficient attention on what should be the central inquiry-whether the woman consented to the act of intercourse in question.

\section{Legal Discussion of a Consent Standard}

The law's failure to develop a well-defined concept of consent in rape, its strong tendency to rely on categorical assumptions in dealing with issues surrounding the central issue of consent, and the biases built into those categorical assumptions mirror the tone and substance of legal debate on consent in rape set in the early part of this century. At a time when the political climate is ripe for reforming archaic rape laws, it is imperative to examine why the law failed to develop a standard of consent in rape law and to identify the policies that should mold such a standard before attempting to apply the concept through legislative or judicial rules.

Scholarly discussion on consent in rape gelled in an era when legal thinkers were emotionally distrustful of rape complaints in general, but were fascinated by cases where consent was allegedly induced by subterfuge. Thus when J.H. Beale sparked the discussion in $1895^{81}$ he granted that force or terror could negative a victim's apparent consent, ${ }^{82}$ but he focused on cases where fraud deceived the mind into agreement. According to his theory, if a person consented to one specific act, and additional acts were done to that

${ }^{\mathrm{x} 0}$ Low reporting and conviction rates buttress this finding. See notes $10 \& 14$ supra. The existence of this prejudice explains the prevailing view that a rape complainant is more on trial than the defendant. See State v. Stegmann, 286 N.C. $638,647-48,213$ S.E.2d 262, 270 (1975) (prosecution presents 14 good character witnesses). See also BrownmiLLER, supra note 6, at 372; Landau, supra note 18; Note, supra note 30 , at 351 .

"I Beale, Consent in the Criminal Law, 8 HaRv. L. Rev. 317 (1895) [hereinafter cited as Beale].

${ }^{82}$ Id. at 321 . Such cases were limited to threats of immediate injury to person or property. 
person, then there had been no consent to the additional acts. If, however, there was but one act involved, to which a person consented under the inducement of fraud, then consent to that one act existed..$^{83}$ Beale therefore concluded that if a woman agrees to sexual intercourse with a man impersonating her husband or a doctor who assures her the act is medical treatment, she has consented to the "one act" of physical connection and no rape has been committed. ${ }^{8+}$ But because the woman has not consented to the additional element of losing her chastity, the husband impersonator or wily doctor should be convicted of assault and battery. ${ }^{85}$

The Irish Law Times immediately published an anonymous critique of Beale. ${ }^{86}$ The commentator argued that a theory of consent in the criminal law is viable only if its basic tenets can be integrated with other fields of law, "subject to such modifications as may be necessitated by considerations peculiar to criminal law or by statutory requirements." 87 Examining the requisites for effective agreement in contract and consent in tort, he concluded that, in the criminal law, if a person has fraudulently procured consent or has taken advantage of another's misapprehension, ${ }^{88}$ consent does not exist. Therefore, fraud going to the identity of the actor or to

${ }^{*}$ For example, if a person accepts a fig that has poison in it, he does not consent to the additional element of poison. If he accepts poison in the shape of a fig, he has consented to receiving the substance he was given, even though the consent was based on a misapprehension. Id. at 317-18. Beale saw no sense in the argument that one consents only to what one thinks is happening: in this case, accepting an edible fig.

"Id. at 320,326 .

ns Beale thought that intercourse induced by fraud was not rape because the physical connection, having been consented to, was not an injury to the public. See id. at 323. The loss of chastity, not having been consented to, was an injury to the public. Id. at 326 . Therefore the man should be punished; but if the woman had consented to the physical connection, how can a charge of battery lie? Beale's answer was that the man "has committed a technical battery; and if we say that the consent of the woman shall not . . . protect [him] from prosecution, we may punish him." Id.

It is apparent that Beale's reasoning was entirely result-oriented. Even on the basis of his own theory, a more logical legal result is that because the physical connection was consensual, there was no battery; but because the loss of chastity was not consensual, there is a basis for a rape charge.

"Consent in the Criminal Law, 29 IR. L.T. 427 (1895) (anonymous article reprinted from the Madras Law Journal) [hereinafter cited as IR. L.T.]. The commentator suggested that Beale's declaration that assent induced by force is not consent, while assent induced by fraud is consent, rests either on "bad psychology or bad logic." Id. at 431.

${ }^{x 7}$ Id. at 427.

* Where a sexual act is committed on an unconscious, drugged or intoxicated person, or on an imbecile, apparent consent based on lack of resistance is not legally valid. See Commonwealth v. Burke, 105 Mass. 376 (1870) (intoxication); Regina v. Fletcher, 169 Eng. Rep. 1168, 8 Cox Crim. Cas. 131 (C.C.A. 1859) (imbecile); Regina v. Mayers, 12 Cox Crim. Cas. 31 (N. Cir. Man. 1872) (sleeping woman). 
the nature of the act will negative consent. If, however, the complainant was deceived only as to the consequences of the act, the fraud will not vitiate the consent. ${ }^{89}$ Thus the commentator concluded that a husband impersonator or a guileful doctor is guilty of rape, as well as assault and battery, because his victim has not legally consented to either the touching or the loss of chastity involved in the intercourse at issue..$^{00}$

In a 1925 article with the misleadingly broad title Consent in Rape, Professor Ernst Puttkammer reexamined consent in rape claims where the defendant either caused or took advantage of a misapprehension in the mind of a woman. ${ }^{91}$ Analyzing the continuum of possible mental states, he concluded that a mental blank due to intoxication or unconsciousness prevents the victim from comprehending the existence of the act and precludes consent. At the opposite extreme, where the woman is fully aware of the situation, she either consents voluntarily or submits to force or duress, without mental consent. ${ }^{92}$ In cases that fall between the extremes,

IR. L.T., supra note 86 , at 430 .

90 The law of the time, though confusing, supports the Irish Law Times approach. Regina v. Barrow, [1868] L.R. 1 Cr. Cas. Res. 156, the major case holding a husband impersonator not guilty of rape, was decided without either side being represented. See also Lewis v. State, 30 Ala. 54 (1857); Regina v. Saunders, 8 Carr. \& P. 265, 173 Eng. Rep. 488 (N.P. 1838). In the Irish case of Regina v. Dee, 15 Cox Crim. Cas. 579 (Ir. Cr. Cas. Res. 1884), the judges held that a successful husband impersonation negatived a woman's consent. While Beale accused the court of confusing consent to an act with consent to a crime, Beale, supra note 81 , at 320 n.1, the Irish Law Times commentator approved of the court's view that the woman had consented only to intercourse with her real husband. IR. L.T., supra note 86, at 430 . Moreover, the convictions of rape in Regina v. Flattery, 13 Cox Crim. Cas. 388, 2 Q.B.D. 410 (C.C.A. 1877), and of assault in Regina v. Case, 169 Eng. Rep. 381 (Cr. Cas. Res. 1850), where men who purported to be medical personnel had intercourse with young girls who consented in the belief that they were undergoing medical treatment, were clearly based on the fact that each girl had consented to something wholly different than what was done, and therefore had not consented to the sexual act at all.

The relative accuracy of the two theories in explaining the case law of the day can be measured by the renowned case of The Queen v. Clarence, 22 Q.B.D. 23 (1888), in which the court held that the defendant did not commit assault by infecting his wife with a venereal disease, which he knew he had, during consensual intercourse. Though Beale could argue that she consented to one integrated act of intercourse, it would seem more consistent with his theory to view the connection as consensual sexual intercourse plus fraudulent administration of a poison, to which she did not consent. Compare note 83 supra with the instant case. On the other hand, under the Irish Law Times approach, she was not deceived as to the nature of the sexual contact or the identity of the man involved, and therefore consented to whatever consequences the act entailed. IR. L.T., supra note 86 , at 430 . Though even this cutoff point was arbitrary, it did reflect the existing judicial limits on nonconsent in fraud and mistake cases.

91 Puttkammer, Consent, supra note 27.

${ }^{92}$ Puttkammer noted that the law was confused as to whether force was a separate element of the crime or an indicator of consent. Id. at 415. Modern courts have in practice followed the latter course. See text and notes at notes 8 \& 38 supra. 
Puttkammer rejected the Irish Law Times nature-identity and consequences distinction, instead applying a strict "nature of the act" test. ${ }^{93}$ Under this theory, a woman who had intercourse with a husband impersonator would not be a rape victim because she understood the sexual nature of the act. A naive woman who had intercourse with a man she believed to be a doctor administering medical care, however, would be.

Puttkammer's article marks three crucial ways in which the legal discussion of consent in rape was diverted from a fair and useful development. First, an affinity for sensational cases of husband impersonation and lewd medical examinations limited subsequent rape commentary to fraud and mistake situations, though such instances are far outnumbered by cases involving duress or force. Second, while Beale and his colleagues had created theories of consent based on machinations of logic and open to legal debate and development, Puttkammer presented a definitive standard based on his assumptions about rape victims and directed towards rape trial expediency. In all fraud cases, doubts as to the credibility of the complainant are magnified by the absence of such outward indicia of nonconsent as force and resistance. Where the circumstances of allegedly fraudulently induced intercourse suggest a high probability of consent and ample motivation for the complainant to explain the act as rape, Puttkammer feared jury sympathy for the complainant would lead to unjustified convictions. ${ }^{94}$ In such cases Puttkammer urged that the courts use per se categories of consent rather than permit the jury to attempt to separate the presumably small number of sincere claims from the false ones..$^{95}$ In short, the contours of consent were to be shaped by distrust of rape charges and by a priori expectations of evidentiary problems and jury sympathy for complainants.

Third, and perhaps most importantly, Puttkammer reaffirmed the prevailing view that the role of consent in rape is sufficiently unique to defy comparison with any general legal theory of consent or with consent in other fields of the law. ${ }^{98}$ In a companion article on consent in criminal assault, ${ }^{97}$ he argued that consent is a descrip-

13 Id. at $422-24$.

"Id. at 421-22.

is Id. at 422 .

" For example, Puttkammer compared larceny with rape and concluded that while a larceny victim is under no inducement to hide the fact of the crime, accuse an innocent person or push an unfair accusation to conviction, an alleged rape victim possesses all of these motivations. Id. at 421-22.

"Puttkammer, Consent in Criminal Assault, 19 ILl. L. Rev. 617 (1925) [hereinafter 
tive legal word which can be defined only in relation to the particular type of crime at issue..$^{98}$ While Puttkammer correctly recognized that policy considerations may influence the legal requirements governing consent in particular crimes, he failed to explore the law's overall purpose in allowing consent defenses and requiring nonconsent as an element of certain crimes. Ironically, he weakened his own position by applying the framework he developed in his rape article to his analysis of consent in assault. ${ }^{99}$ Thus Puttkammer's argument for separating a theory of consent in rape from consent in other areas of the law was based more on prejudiced assumptions than on the purposes unique to the crime of rape.

Nonetheless, since 1925 the sparse legal. discussion of consent in rape has remained focused on cases of intercourse induced by fraud, as lawyers, legislatures and courts have attempted to define and apply variations of Puttkammer's "nature of the act" test in an acceptable way. ${ }^{100}$ These discussions continue to assume that, where a situation suggests a woman's voluntary assent to an admitted act of intercourse, the law can fairly presume consent and thereby avoid drawing fine distinctions. ${ }^{101}$ In addition, legal commentators who broach the popular topic of consent in the criminal law or in other legal areas pointedly ignore rape. Content to note that legislatures have specifically defined rape to require nonconsent as an element, writers assume that public policies behind rape are well-settled and so unique as to offer nothing to general policy analyses of consent. ${ }^{102}$ However, the notions of public policy and morality which play such

cited as Puttkammer, Assault].

${ }^{p x}$ Id. at 618-19.

"Puttkammer's assertion that a man who infects his wife with a venereal disease has committed battery, while intercourse in the guise of a medical examination is not assault, shows that he applied a "nature of the act" of touching test to determine consent in cases of assault or battery by fraud. Cf. id. at 624-26.

${ }_{100}$ See Regina v. Maurantonio, 65 D.L.R.2d 674 (Ont. Ct. App. 1967); Rex v. Harms, [1944] 2 D.L.R. 61 (Sask. Ct. App. 1943); Papadimitropoulos v. The Queen, 98 Commw. L.R. 249 (Austl. 1957); Rev. Stat. CaN. $\$ 143$ (b)(iii) (1970); Hooper, Fraud in Assault and Rape, 3 U.B.C.L. Rev. 117 (May 1968); McCann, The Nature and Quality of the Act: A Reevaluation, 3 OTTAwA L. Rev. 340 (1968). One exception to this trend is an article which investigates the purpose of requiring nonconsent in rape. The author uses Freudian terms to suggest that the consent standard serves a societal need to channel sexual activity into marriage. Note, Forcible and Statutory Rape: An Exploration of the Operation and Objectives of the Consent Standard, 62 YaLE L.J. 55 (1952).

101 See Hooper, supra note 100, at 121; McCann, supra note 100, at 346.

${ }_{102}$ See Hughes, Consent in Sexual Offences, 25 Mod. L. Rev. 672, 673 (1962) [hereinafter cited as Hughes]; Williams, Consent and Public Policy, 1962 Crim. L. Rev. 74, 154 [hereinafter cited as Williams]. But see Note, Consent as a Defense to Crimes Against the Person, 54 Dick. L. Rev. 186 (1950) (examining consent in other areas through criteria developed for rape). 
an important role in defining the working limits of consent in an alleged rape case remain largely unarticulated.

This dearth of legal discussion on consent standards in rape situations has resulted in an indiscriminate transposition of the standards of consent developed in the rape by fraud cases to the broader class of cases where the defendant allegedly used force, duress or threat of physical harm to coerce submission. Judicial requirements that the prosecution prove certain levels of assailant force and victim resistance, which are applied strictly only when the complaining witness's veracity is doubtful ${ }^{103}$ or the circumstances of the allegedly forcible intercourse appear questionable, ${ }^{104}$ are a form of line-drawing based on expectations of female consent. While there is some flexibility in these requirements, certain categories of suspicious and credible circumstances have developed. Evidence of the complainant's virginity suggests nonconsent, in much the same way that ignorance of the sexual nature of intercourse will vitiate a young woman's consent in a fraud case. Where the alleged victim did not know her attacker and did not behave in what is thought to be a sexually suggestive manner, the court will not presume consent or motive to bring a false claim. In contrast, evidence of prior sexual experience is thought to indicate that the complainant understood the imminence of intercourse and was capable of refusing. Similarly, supposedly precipatory behavior implies that the alleged victim invited and voluntarily submitted to sex, misunderstanding, at most, how or when actual intercourse would occur.

While the categories that the early commentators shaped for fraud cases were explicitly based on claims of trial expediency, which were in turn based on prejudicial views of rape charges in general, these semantic distinctions and practical concerns may have been justified, or at least relatively harmless, in cases involving husband impersonators and dissembling doctors. But similar considerations do not justify prejudging rape claims on credibility grounds in nonfraudulent situations. First, although a woman's sexual choice is violated by any undesired intercourse, the chance of physical harm is minimal in a fraud situation where the alleged rapist depends solely on guile. Even Beale and Puttkammer conceded that a certain level of force or duress would preclude effective consent, regardless of a woman's knowledge of the nature, quality or consequences of sexual intercourse. ${ }^{105}$

${ }^{103}$ See text and note at note 34 supra.

ios See text and note at note 65 supra.

${ }^{105}$ Beale, supra note 81, at 321-22; Puttkammer, Consent, supra note 27, at 415 \& n.18 
Second, the injury to a woman's rights in a nonfraudulent rape situation is more severe than in the classic fraud hypotheticals. When a man has sexual intercourse with a woman who is unconscious, believes he is her husband, or does not know the nature of intercourse, he has deprived her absolutely of sexual choice and therefore deserves punishment as a rapist, though his victim was unaware of the invasion of rights when it occurred. When a woman assents because a man assures her he is willing to marry her or free from venereal disease, she can fairly be said to have exercised her freedom of sexual choice; the law rightfully refuses to protect her from her own priorities. ${ }^{106}$ In contrast to both these types of situations, when a woman is beaten or faces credible threats of harm, she must make a necessarily traumatic choice between risking serious bodily harm by resisting or consciously submitting to an unwanted sexual act, which may still entail brutality. This Hobson's choice magnifies the resulting harm to her rights of sexual choice and physical safety substantially beyond the injuries worked by fraud-rape. ${ }^{107}$

Third, the credibility questions in fraudulent and nonfraudulent rape cases are not comparable. Because a modern jury doubtless would be as reluctant to believe that a woman did not know the difference between intercourse and a medical examination as it would be to credit a rape charge based on husband impersonation or unfulfilled promises of marriage, the nature-identity-quality distinction is largely of academic interest. ${ }^{108}$ Credibility issues may be close, however, where the prosecution alleges submission to intercourse only under application or threat of force and the defendant claims uncoerced consent by the complainant. Without comparing the two classes of cases, judges and commentators have assumed that the jury cannot deal with the credibility issues in nonfraudulent cases without the aid of categorical distinctions, based, as in fraud cases, on supposed probabilities of consent. While the natureidentity-quality distinction is clearly inappropriate to forcible rape situations, categories based on the complainant's virginity, resistance or general behavior, or even on the defendant's display of force,

(by implication). See also Ir. L.T., supra note 86, at 429.

${ }^{106}$ Cf. McCann, supra note 100, at 346: "[Rape law] must ensure the protection of women only from unwanted sexual advances and should not pretend to protect them from themselves, with one exception, namely, that of the young and naive."

${ }^{107}$ See Weis \& Borges, supra note 66, at 99.

10x Although there are few modern fraud-rape cases, the proposed federal criminal code recognizes that intercourse induced by fraud as to the nature of the act or the identity of the actor, as well as intercourse with an unconscious woman, is a sexual crime. S.1, 94th Cong., 1st Sess. $§ 1642$ (1975). 
do not solve credibility problems or neutralize jury biases. The legal community must instead situate rape within the learning on consent in the law, and especially the criminal law, before the purposes and boundaries of consent in rape can be rationally comprehended and embodied in the working law of rape.

\section{CONSENT IN THE LAW}

In any situation where $A$ claims to have been injured by an act of $B$, and $B$ defends himself on the ground that $A$ assented to the act which caused the harm, the legal system must decide whether $A$ 's assent should absolve $B$ of responsibility for $A$ 's injury. If lawmakers decide that it should, then they must determine the conditions and limits of effective consent. ${ }^{108}$ In making the first decision, lawmakers must balance the policy of legal respect for $A$ 's freedom of personal choice against the policy of protecting $A$ and society from the injurious consequences of $B$ 's acts. In making the second set of determinations, they must consider both of those policies and other subsidiary factors.

\section{A. The Policy Extremes: Cases Where Consent Plays No Legal Role.}

Protection of social well-being overrides respect for individual free will in crimes where grievous bodily harm is inflicted by one person on another. A murderer does not have the defense of his victim's consent. ${ }^{10}$ One cannot consent to mayhem because "[o]ur government is deeply concerned, financially and otherwise, for the health of its citizens and that they do not become a public charge."'111 In cases of aggravated battery, victim consent will not protect the defendant from criminal liability. ${ }^{112} \mathrm{~A}$ person cannot

103 Technically, the legal community defines consent as "willingness" that an act shall occur. W. Prosser, Law of TorTs $\$ 18$, at 101 (4th ed. 1971). This may be manifested by words, conduct or silence. See Walker, Silence is Consent, 108 YALE L.J. 791 (1958).

110 Williams, supra note 102 , at 77 . He points out that paternalistic laws will succeed only if they reflect prevailing social attitudes. For example, juries would not convict a duel participant for murder of his consenting partner until social attitudes changed to disapprove of the practice.

III State v. Bass, 255 N.C. $42,50,120$ S.E.2d 580, 586 (1961). In this case, a doctor who administered anesthetic to a man's hand, knowing of his plan to have his fingers sawed off in order to obtain insurance money, was convicted as an accessory before the fact of mayhem.

112 The traditional example is prizefighting, where the objective is to subdue the opponent with violent blows. While jurisdictions differ over the effect of consent to prizefighting on civil damage claims, there is no disagreement as to criminal liability. "[I] $t$ is not in the power of any man to give an effectual consent to that which amounts to, or has a direct tendency to create, a breach of the peace." Regina v. Coney, 8 Q.B.D. 534, 553 (1882). 
effectively consent to sadomasochism, if the blows received are likely to do bodily harm or, to use the classic formulation in Regina $v$. Donovan, "to interfere with the health or comfort of the prosecutor." 113 The law simply does not tolerate a consent defense where the probable injury to person and society resulting from exercise of personal choice is great and where such an exercise can serve no major useful purpose. In addition, lawmakers declare some classes of persons incapable of consenting to criminal or tortious contact because of their imbecility, senility, unconsciousness or age. ${ }^{114}$ Thus a female under a set age is not legally capable of consenting to sexual intercourse because society is determined to safeguard her morals whether she comprehends the nature of the act or not. ${ }^{115}$

At the other end of the spectrum lie cases where social harm is so small and so hard to deter that the law refuses to interfere with personal freedom of choice. A person complaining of tortious assaults and batteries inflicted in pedestrian traffic or other everyday interactions faces the defense of volenti non fit injuria, for the law implies that he assumed the risk of daily life. ${ }^{116}$ A player of a violent sport is deemed to consent to use of moderate force, inflicted within the rules of the game or, if expected, in breach of the rules. ${ }^{17} \mathrm{~A}$ spectator at a sporting event is held to accept the risk of injuries he may receive in the course of the game. ${ }^{118}$ Despite the serious, sometimes fatal, injuries suffered by athletes and spectators during play, society's decision to allow free choice of recreation supersedes concern for the safety of voluntary participants.

${ }^{113}$ Regina v. Donovan, [1934] 2 K.B. 498 (conviction for indecent assault where defendant caned a consenting 17 year-old girl for purposes of his sexual gratification).

II W. Prosser, supra note $109, \S 18$, at 102.

115 Id. at 107-08. "If she licenses him to corrupt her morals, the license is void and the consent is no defense. The vicious propensities of the child did not excuse the conduct of the accused." People v. Gibson, 232 N.Y. 458, 462, 134 N.E. 531, 532 (1922).

116 See W. Prosser, supra note 109, § 18, at 101; Bohlen, Voluntary Assumption of Risk, 20 HaRv. L. REv. 14 (1906).

117 See W. LaFave \& A. Scott, Handbook on Criminal Law $\S 81$, at 608 (1972); Williams, supra note 102 , at $80-81$.

${ }_{11 *}$ There has been much disagreement as to whether this is so because consent lowers the standard of care required of the proprietor and the athletes, thereby making the prima facie case of negligence more strict, or because the spectator has attended at his own risk, thereby giving the defendant a defense of volenti. Compare Dworkin, Injuries to Spectators in the Course of Sporting Activities, 25 MoD. L. Rev. 738 (1962), with Siskind, Liability for Injuries to Spectators, 6 OsGoode L.J. 305 (1968). 


\section{B. The Nature and Scope of Effective Consent}

These extreme cases, where the law either does not permit a person to consent to serious harm or forces him to bear full responsibility for the consequences of his consent, play a minor role in the overall doctrine of consent. In most cases of allegedly consensual personal harm, recognition of personal responsibility competes with social policies of physical protection. In these cases legislatures and courts authorize a victim nonconsent requirement or a consent defense and then determine the circumstances under which the victim will be held to have consented to the conduct at issue. In some instances consent is defined so as to emphasize the policy of physical protection, while in others the definition emphasizes the policy of freedom of choice. The law also manipulates the scope of conduct to which a person is held effectively to have consented in ways that further one or both of these policies. Finally, in defining consent, the legal system considers the nature and level of coercion that effectively prevents an exercise of free choice. Subsidiary policies and evidentiary considerations sometimes affect the legal requirements for effective consent.

While courts and commentators agree that a single, allencompassing definition of consent is neither possible nor desirable, they also agree that discussions of consent should acknowledge the policies that influence the use of basic principles relevant to consent questions. ${ }^{119}$ Moreover, established views of consent are expected to conform to changes in social policy over time. ${ }^{120}$ Because the crime of rape is not classed with murder and mayhem, or with minor tortious assaults, it must take its place within this broad, flexible framework of consent. Principles that should guide the current controversy over consent in rape can be derived from an examination of the policies that govern the meaning of effective consent in other situations where one person violates another's safety and freedom of choice.

1. Protection of Physical Safety. In some situations the law uses a consent element to encourage a person to subordinate his freedom of choice to his personal wellbeing. For instance, robbery and assault, like rape, are crimes which are defined to include both

1' For a discussion of the confusion that results when the law attempts to base decisions on a single definition of consent, rather than acknowledge policy grounds, see Note, Consent, Liability and Guilt: A Study in Judicial Method, 7 Stan. L. REv. 507 (1955). See also Hughes, supra note 102, at 685; McCann, supra note 100, at 341; Williams, supra note 102, at 159.

120 See generally Dias, Consent of Parties and Voluntas Legis, 1966 CAMB. L.J. 75. 
force and nonconsent as elements. ${ }^{121}$ Although these definitions reflect a recognition that most transfers of property and most touchings are consensual and that a person needs the freedom to engage in these activities, this recognition does not expand into a legal expectation that one who charges commission of these crimes does so falsely. Instead, the law interprets consent so as to further the policy of physical protection by focusing on the behavior of one who inflicts harm rather than on the actions of one who receives it. In robbery cases the courts set a low standard of force to prove victim fear and hence nonconsent, applying a reasonable man test. ${ }^{122}$ This policy is consistent with the advice of law enforcement officers to give up property when confronted by a thief, and to run or at least protect vital organs when assaulted. The law does not expect a person to risk serious injury or death in defense of self or property.

Like robbery and assault, rape is a nonconsensual and forcible version of an ordinary human interaction. Yet only the law of rape makes unjustified adverse assumptions about the general sincerity of alleged victims, which lead to requirements of much higher levels of proof of force and resistance. Such requirements leave the physical safety of women correspondingly less protected in cases of rape than in cases of robbery or simple assault. At a time when police and public interest groups advise women to submit to rapists in order to minimize physical injury, courts should apply the reasonable man standard developed in robbery cases to determine consent and allow juries to evaluate available evidence of force, fear and resistance as indicia of consent, rather than holding particular levels of these criteria to be absolute prerequisites for convictions.

2. Protection of Freedom of Choice. In other instances the law interprets a consent element so as to emphasize its function of protecting freedom of choice, regardless of the magnitude of physical danger involved. For instance, the law permits a person to con-

121 See Hughes, supra note 102, at 673-76; Puttkammer, Assault, supra note 97, Puttkammer, Consent, supra note 27 . While many modern codes no longer specifically define assault and robbery to be against the victim's will, the burden of proving nonconsent remains on the prosecution.

${ }^{122}$ Under this test courts generally judge the alleged victim's actions in light of all the circumstances. See, e.g., People v. Carleton, 31 Ill. App. 3d 313, 315, 333 N.E.2d 596, 598 (1975) (display of razor and slapping of victim); Hazelwood v. State, 538 P.2d 1072, 1075-76 (Okla. Crim. App. 1975) (where gun pointed at victim, no need to prove actual fear); Emerson v. State, 476 S.W.2d 686, 687-88 (Tex. Crim. App. 1972) (alleged robber's action of placing hand in pocket and bulge in his sweater, coupled with his command to storekeeper to present money, held sufficient to produce fear of bodily injury). Some cases hold fear of loss of chastity or fear of conspiracy against character to be sufficient to show a taking against the victim's will. See Consent or No, 122 Justice of the Peace \& LoCAL Gov'T Rev. 101 (1958). 
sent to certain kinds of nonmalicious physical intrusions, like surgery, but his consent will be an effective defense to an assault or battery prosecution only if the consent was informed..$^{123}$ As the same standard of consent is required for minor and major operations, for cosmetic as well as lifesaving operations, it is clear that the standard is not related to the severity of potential physical harm. Instead, these rules reflect a policy decision to protect an individual's freedom of choice where his own body and health are concerned, to ensure that he understands the nature and consequences of his options before he is held responsible for his decisions. ${ }^{124}$

The same policy underlies the law's willingness to recognize as rape at least some cases of intercourse induced by fraud. As seen above, the triers of fact in such cases ignore the fact that the defendant neither used nor threatened coercive force, and hence the victim's physical safety was not endangered. Instead, they evaluate what facts the complaining witness knew and understood, in an effort to decide whether she made a choice on the basis of information sufficient to relieve the other party of liability. In contrast to their current approach in other informed consent situations, and without adequate justification, the courts in fraud-rape cases have employed a highly restrictive notion of how much information is sufficient.

The law also defines consent to protect individual freedom of choice in another, broader sense. Returning to the example of robbery, it is clear that, although a flagrant display of cash in public may very predictably precipitate a robbery, the law does not hold an alleged robbery victim responsible for his own foolishness in making such a display. Nor is an assault victim asked to answer for his walking on the street or being alone in his house after dark. The

123 See, e.g., Canterbury v. Spence, 464 F.2d 772 (D.C. Cir. 1972) (patient must be informed of risks and probable consequences of surgery before his consent is effective). The only exceptions to these requirements occur when an emergency requires immediate medical care or when disclosure of the risk would jeopardize the patient's health. W. PROSSER, supra note $109, \S 18$, at 104 .

${ }^{125}$ A striking example of this policy is embodied in legislation and judicial decisions declaring the requirements for effective consent to sterilization for therapeutic or contraceptive purposes. A typical modern statute negates traditional criminal liability for nonnegligent performance of a therapeutic sterilization only if: (1) a doctor performs it at a licensed hospital pursuant to written request of the patient and with the consent of the patient's spouse; (2) the physician has fully explained the nature and consequences of the operation and obtained the concurring opinion of at least one consulting doctor; (3) 30 days have elapsed between the written request and the operation; and (4) the patient and spouse have signed hospital and physician's consent forms. 21 AM. JUR. Proof of FACTs $\$ 104$, at 417-418 (1968) (annotation of state law on this subject). 
law does not expect a citizen to structure his activities around avoidance of robbery or physical assaults.

Rape law, however, tends to permit or encourage the trier of fact to weigh evidence of supposedly precipitating behavior against the prosecution in deciding the issue of consent. In so doing the law serves to limit a woman's freedom to live an ordinary life; ${ }^{125}$ in effect, it urges every woman to be cautious, suspicious, even fearful in all she does. ${ }^{126}$ In rape cases as in other crimes, the legal system should concentrate on deterring wrongdoers from harmful activity, not on deterring the innocent from harmless activity which is unjustifiably labeled precipitating.

3. Scope of Effective Consent. Another way in which the law of consent serves to protect physical safety and freedom of choice is by setting limits on the scope of injury to which an individual can effectively consent. For example, where fraternity brothers brutally beat a pledge during hazing, his willingness to undergo initiation rites is not a defense to a prosecution of the brothers for assault. ${ }^{127}$ Similarly, an athlete who maliciously inflicts serious injury on another player can be prosecuted for aggravated assault because consent to the dangers of violent sports is held not to encompass blows specifically intended to cause grievous bodily harm. ${ }^{128}$ In short, even where a person has voluntarily placed himself in a situation that entails some danger of physical injury, society will protect him from intentionally inflicted harm that exceeds the risks he can fairly be said to have assumed. Strict limitation on the scope of effective consent can also protect freedom of choice, even where no physical harm results from exceeding that scope; a plaintiff's consent to one kind of surgery is held an inadequate defense to a civil action for battery based on even successful surgery of another kind. ${ }^{129}$

In contrast to the cases above, the working law of rape demonstrates little sensitivity to the idea of limited consent. A woman who agrees merely to have a drink, go for a ride or engage in petting with a man, or who has had consensual sexual experiences

${ }^{125}$ See note 67 supra.

${ }^{128}$ See Weis \& Borges, supra note 66, at 94.

${ }^{122}$ People v. Lenti, 44 Misc. 2d 118, 253 N.Y.S.2d 9 (Nassau County Ct. 1964). The beatings in this case were so severe that one pledge remained in the hospital for several weeks.

${ }^{128}$ For a discussion of the Dave Forbes case, where a professional hockey player was indicted for aggravated assault with a dangerous weapon after intentionally striking another player in the face with the butt end of his stick, see Comment, Violence in Professional Sports, 1975 WIs. L. REv. 771.

${ }^{129}$ Mohr v. Williams, 95 Minn. 261, 104 N.W. 12 (1905); see C. Gregory \& H. Kalven, Cases and Materials on Torts 24-28 (2d ed. 1969). 
often is held to have consented, by those actions, to a particular act of intercourse with a companion. Though her freedom of choice is no less violated than that of a patient who did not consent to particular surgery, and though her physical injuries are often more severe than the fraternity boy's or the athlete's in the examples above, only she is held legally responsible for unlimited consent to harm.

The most dramatic example of the law's failure to place limits on the scope of effective consent in rape cases is the legal fiction that marriage constitutes consent to all marital sexual relations, no matter how brutal or unwelcome. ${ }^{130}$ Though this practice may be justified by judicial policy decisions to avoid the emotional issues and proof problems involved in family disputes, or to encourage parties in an ongoing relationship to resolve problems privately, ${ }^{131}$ the courts rarely articulate policy grounds for decisions in this area. Were they to do so, they would be forced to recognize that there are strong policy considerations behind the criminalization of rape which disclose the unfairness and danger of uncritical, universal application of this legal fiction.

4. Consent in Relation to Coercion. In structuring the law of consent in particular fields, the law must resolve what kind and amount of coercion will distinguish submission from consent. The law's answer to this question depends on a number of factors; the value placed on the personal freedom to make various kinds of choices; the severity of the damage which different types of coercion are capable of inflicting; the amount of resistance to coercion that the law expects of victims; and the degree to which coercion can serve an evidentiary function in determining issues of fact with respect to nonconsent.

Where society places great value on freedom to make a particular kind of choice, the law imposes minimal standards on the kind and amount of coercion that will preclude effective consent. In the law of search and seizure, for instance, warrantless searches by state officers are legal under the fourth and fourteenth amendments only if the person whose privacy interests are encroached voluntarily submits to the search. ${ }^{132}$ In deciding whether officers placed undue pressure on a person to assent to a specific search, courts apply a

${ }^{130}$ See generally Comment, Rape and Battery Between Husband and Wife, 6 STAN. L. Rev. 719 (1954). Although a husband cannot legally rape his wife, he can be found guilty as an accomplice of another who does. See, e.g., Rozell v. State, 502 S.W.2d 16, 17-18 (Tex. Crim. App. 1973).

131 See Comment, supra note 130.

132 See, e.g., Bumper v. North Carolina, 391 U.S. 543, 548-49 (1968). 
"totality of the circumstances" test, examining the characteristics of the individual and the circumstances of the search. ${ }^{133}$ To best protect fourth amendment interests, courts require that effective consent be informed, specific to the scope of the search, ${ }^{134}$ and uncontaminated by any physical or mental coercion. ${ }^{135}$ Although the target of a warrantless search might be motivated to fabricate testimony of nonconsent, and although his word will often be challenged by the account of the officer who conducted the search, the courts do not require a showing that physical force was used or resistance mounted as external evidence that subjective consent actually was withheld. ${ }^{136}$

In other situations the social value of freedom of choice is overshadowed by other concerns. For example, the law accepts duress as a defense to a criminal charge because legal responsibility presupposes the freedom to choose not to commit a crime. Theoretically, when a person commits a criminal act under compulsion, punishment would be neither fair nor an effective deterrent. In practice, however, the law recognizes criminal duress only when the alleged victim can prove not only that he faced an imminent threat of great bodily harm and offered utmost resistance, but also that he was not responsible for creating the situation that invited duress. ${ }^{137}$ Despite the admirable policy behind allowing duress as a defense, these standards emerged because:

If the doctrine was not to be the plaything of the shrewd and unscrupulous .... it had to be well hedged and strict of proof. . . . The standards devised were . . . not so much cal-

${ }^{133}$ Schneckloth v. Bustamonte, 412 U.S. 218, 223-26 (1973).

${ }_{134}$ United States v. Dichiarinte, 445 F.2d 126 (1971).

${ }_{135}$ Simmons v. Boman, 349 F.2d 365, 366 (6th Cir. 1965). The courts consider an official's claimed authority to search on the basis of warrant as tantamount to an assertion to the suspect that he has no right to resist the search. No consent will justify the search if the warrant is invalid. Bumper v. North Carolina, 391 U.S. 543, 548-50 (1968). Where an officer obtains permission to search only by declaring "I am here to search the premises" and demanding admission, the courts generally view the search as coerced. Amos v. United States, 255 U.S. 313 (1921). See also Higgins v. United States, 209 F.2d 819 (D.C. Cir. 1954); Judd v. United States, 190 F.2d 649 (D.C. Cir. 1951) (when one under arrest gives an armed policeman permission to search his home, there is an insufficient showing of consent).

${ }^{136}$ This is not to say courts do not prejudge some search cases on biased credibility grounds. In one case, the trial judge denied a motion to suppress evidence because the police were "gentlemen of probity" and the defendant was "unworthy of belief" in light of a past arrest record. The court of appeals did not reach the credibility issue because the government had not met the standard of showing true consent under the facts of the circumstances. Judd v. United States, 190 F.2d 649, 652 \& n.8 (D.C. Cir. 1951).

${ }^{137}$ Newman \& Weitzer, Duress, Free Will and the Criminal Law, 30 S. CAL. L. Rev. 313, 314-15 (1957). 
culated to show that the actor (within a particular set of circumstances and given the peculiarities of his nature) was actually deprived of his free will as claimed, as much as they were intended to set limits upon the circumstances in which the doctrine could be applied. ${ }^{138}$

In addition to serving an evidentiary function, the requirements of imminent danger and utmost resistance protect innocent third parties by encouraging a victim of duress not to commit criminal acts demanded of him unless the pressures are in fact intolerable.

Ironically, the balance struck among the factors involved in the decision as to the kind and amount of coercion that will prevent effective consent in rape law is much closer to that struck in the law of duress than in the law of search and seizure. By defining rape to include the elements of both force and nonconsent, the law protects alleged rape victims only from coercion in the form of actual or threatened physical harm. At the same time, formal requirements of particular levels of force and resistance are considered necessary to test the credibility of the victim's account of subjective nonconsent against external evidence thereof. Notions of antecedent contributory fault influence the legal system's view of a complainant's charge of rape, much as they do in view of a defendant's claim of duress. But, assuming that justification exists for the wide gulf between the law's treatment of a defendant's claims of duress and of nonconsent to a search, one would expect the law of consent in rape to resemble more nearly consent standards in search and seizure than in the law of duress. Though the requirements of physical force and victim resistance in the law of duress may be necessary to protect third parties from harm, they perform no such function in either search and seizure or rape law.

One need not argue that the rights of rape victims deserve the same solicitude as the constitutional rights of criminal defendants in order to suggest that courts' fair and realistic treatment of claims of nonconsent to searches can contribute to legal treatment of the consent issue in rape trials. At a minimum, if it is "not in accordance with human experience" for a person subjectively to consent to searches made under clear, if unspoken, threats of physical harm, ${ }^{139}$ neither is it realistic to expect a woman so to consent when confronted by an armed man or a potentially violent man demanding sexual intercourse. Indeed, since the basic element of rape is

13* Id.

139 Judd v. United States, 190 F.2d 659, 651 (D.C. Cir. 1951). 
nonconsent and the basic value protected by that element is freedom of choice, then the law should recognize that forms of coercion other than threats or infliction of bodily harm preclude effective consent to intercourse.

Modern courts have already taken the first step in this direction by holding that threats to harm a third person can prevent effective consent in a rape case, ${ }^{140}$ although such threats in reality are only a form of mental coercion against the complainant. In People $v$. Cassandras, ${ }^{141}$ the court went even further in recognizing nonphysical coercion. There the State proved that the complainant had submitted to intercourse with defendant, who had lured her into a hotel room with an elaborate ploy, only because he threatened to have the hotel clerk report her as a prostitute to the police, who would then take her children away from her. Though, in affirming the rape conviction, the court purported to find evidence sufficient to prove that defendant had threatened his victim with physical harm, ${ }^{1+42}$ the opinion clearly implies that the mental coercion alone sufficed to prevent effective consent. ${ }^{143} \mathrm{~A}$ few foreign jurisdictions have gone yet further by enacting criminal rape statutes under which economic coercion precludes effective consent to intercourse. ${ }^{14}$

It is difficult to predict how far American law will go in recognizing nonphysical coercion in rape cases. Although the force element has traditionally furthered the policy of physical protection, as well as serving an evidentiary function, the role of fraud in rape law demonstrates that freedom of sexual choice rather than physical protection is the primary value served by criminalization of rape. Furthermore, a woman's decision to submit to physical force may be less agonizing than her decision to have intercourse

110 For example, the District of Columbia Circuit has affirmed a rape conviction in a case where the victim offered no resistance to a sexual attack because the defendant had threatened to kill her daughter, who was sleeping in the same room. Hughes v. United States, 306 F.2d 287, 288 (D.C. Cir. 1962). See also Rogers v. State, 249 Ark. 117, 119, 458 S.W.2d 747, 748 (1970); State v. Isham, 235 N.W.2d 506, 514 (Wis. 1975); W. LAFAvE \& A. ScoTt, supra note 117 , at 408 .

1483 Cal. App. 2d 272, 188 P.2d 546 (Dist. Ct. App. 1948).

13283 Cal. App. 2d at 278, 188 P.2d at 550.

${ }^{143}$ In Cassandras there was little doubt as to the truth of the complainant's charge, because another witness testified to rape by the defendant under similar circumstances. 83 Cal. App. 2d at 274, 188 P.2d at 548. Thus there was no reason to demand evidence of physical force or injury in order to test the truth of the complainant's claim of nonconsent.

is For a discussion of the Yugoslav Criminal Code provision that declares whoever "through misuse of his position procures a female person subordinated or dependent upon him to have carnal knowledge, shall be punished by detention for not more than three years," see Donnelly, The New Yugoslav Criminal Code, 61 YaLe L.J. 510, 527-28 (1952). The Soviet and Swiss codes contain similar provisions. Id. at 527-28 n.119. 
with a person who holds economic or emotional power over her and her family. Although one can argue that a man who obtains intercourse through threats of nonphysical harm should be punished less severely than a violent rapist, ${ }^{145}$ the growing legal appreciation of the reality of mental injury ${ }^{146}$ and the power of economic duress ${ }^{147}$ suggests that he nonetheless should be punished. If the law would formalize the unofficial practice of requiring force as an element of rape only where the expectation of the complainant's untruthfulness is not rebutted by extrinsic evidence, and then discard that expectation itself as unreasoned and unreasonable, then the law would very likely conclude that the freedom of sexual choice which is to be protected by rape law can be as effectively negated by nonphysical as by physical coercion.

\section{Conclusion}

Though nonconsent is the central substantive element of rape, the law has yet to develop a principled standard of nonconsent that reflects the interests protected by criminalization of rape. In order to do so, the law should reject the questionable assumptions about rapists, victims and juries that have retarded the development of nonconsent in rape and reexamine the categorical approaches to proof in rape trials developed in the literature. In so doing, the law would not be left with an element in search of a definition, because clear standards of nonconsent have been developed in other areas of the law that also protect freedom of choice and physical safety. Courts and legislatures should draw upon this experience and structure a standard of nonconsent in rape that would allow the triers of fact to examine the totality of the circumstances of an alleged rape to determine if the complaining witness effectively consented to intercourse with the defendant.

Lucy Reed Harris

Is See Note, The Resistance Standard in Rape Legislation, 18 StaN. L. REv. 680, 686 (1966).

Is For example, the law criminalizes the taking of property by blackmail as well as by force. See also Hughes v. United States, 306 F.2d 287, 288 (D.C. Cir. 1972); W. Prosser, supra note $109, \S 18$, at 106 .

it Under contract principles, a clear showing of economic or business duress will render a completed contract voidable, because one party's acceptance was not free. See United States v. Bethlehem Steel, 315 U.S. 289 (1941); Hartsville Oil Mill v. United States, 271 U.S. 43 (1925). See generally S. Williston, Contracts $\S 1603$ (3d ed. 1957). 